\title{
Evaluation of gustatory sensitivity of individuals with Type 2 Diabetes Mellitus and
}

\section{their relatives}

\author{
Avaliação da sensibilidade gustativa de indivíduos com Diabetes Mellitus tipo 2 e seus familiares \\ Evaluación de la sensibilidad gustativa de individuos con diabetes mellitus tipo 2 y sus familiares
}

Received: 03/03/2021 | Reviewed: 03/11/2021 | Accept: 03/13/2021 | Published: 03/20/2021

Talita Batista Matos

ORCID: https://orcid.org/0000-0002-1554-5826

Universidade Estadual do Sudoeste da Bahia, Brazil

E-mail: tali.matos@hotmail.com

Lucas de Almeida Silva

ORCID: https://orcid.org/0000-0002-6307-5080

Universidade Estadual do Sudoeste da Bahia, Brazil E-mail: lukas_silva11@hotmail.com

Gildomar Lima Valasques Junior

ORCID: https://orcid.org/0000-0002-2877-5313

Universidade Estadual do Sudoeste da Bahia, Brazil

E-mail: jrvalasques@gmail.com

Indiara Vieira Santana

ORCID: https://orcid.org/0000-0002-6655-0692

Universidade Estadual do Sudoeste da Bahia, Brazil E-mail: indiarasantana@hotmail.com

Maria Patrícia Milagres

ORCID: https://orcid.org/0000-0002-4845-5624

Universidade Estadual do Sudoeste da Bahia, Brazil

E-mail: mpmilagres@yahoo.com.br

\begin{abstract}
According to the literature reports of both the sensory loss of individuals with type 2 Diabetes Mellitus and of the importance of family interrelationships in the management of this pathology, there is a demand to evaluate the sensory perception of relatives of individuals with type 2 Diabetes Mellitus. Consequently, the aim of this study was to evaluate sweet taste perception of diabetic individuals and their relatives. Methods: For this purpose, a sample of 150 volunteers was invited to participate, which was composed by individuals of both sexes, aged between 18 and 59 years, equally divided into three groups, constituted with 50 volunteers each: non-diabetic individuals, diabetic individuals and relatives. Furthermore, the glucose concentration of all participants was determined by capillary glycemia, and the diabetic participants were referred to a third-party laboratory to perform the glycated hemoglobin test using the immunoturbidimetric. Moreover, a questionnaire of personal and socio-demographic information was applied to diabetic participants and the sensory perception was evaluated through the test for sweet taste sensitivity. Results: The glycemic levels of the diabetic participants given by the Glycated Hemoglobin (HbA1c) test revealed that the results had a mean of $7.92+1.89 \%$, equivalent to $180.60+54.52 \mathrm{mg} / \mathrm{dL}$. The threshold was $3.34 \mathrm{~g} / \mathrm{L}$ for diabetic participants, $2.60 \mathrm{~g} / \mathrm{L}$ for relatives, and $1.92 \mathrm{~g} / \mathrm{L}$ for the control group. Conclusions: Therefore, the present study demonstrated that the threshold index for sweet taste perception is higher in individuals with Type 2 Diabetes Mellitus and their relatives when compared to the control group.
\end{abstract}

Keywords: Taste perception; Diabetes education; Healthy eating.

\section{Resumo}

De acordo com os relatos da literatura tanto sobre a perda sensorial em portadores de Diabetes Mellitus tipo 2, quanto sobre a importância do relacionamento familiar no manejo dessa patologia, existe uma demanda para avaliar a percepção sensorial de familiares de portadores de Diabetes Mellitus tipo 2 Mellitus. Consequentemente, o objetivo deste estudo foi avaliar a percepção do sabor doce em indivíduos diabéticos e seus familiares. Métodos: Para tanto, foi convidada a participar uma amostra de 150 voluntários, a qual foi composta por indivíduos de ambos os sexos, com idade entre 18 e 59 anos, igualmente divididos em três grupos, constituídos por 50 voluntários cada: não diabéticos, diabéticos indivíduos e parentes. Além disso, a concentração de glicose de todos os participantes foi determinada pela glicemia capilar, e os participantes diabéticos foram encaminhados a um laboratório terceirizado para realização do teste de hemoglobina glicada pelo imunoturbidimétrico. Além disso, um questionário de informações pessoais e sociodemográficas foi aplicado aos participantes diabéticos e a percepção sensorial foi avaliada por meio do teste de sensibilidade ao sabor doce. Resultados: Os níveis glicêmicos dos participantes diabéticos dados pelo teste de 
Hemoglobina Glicada (HbA1c) revelaram que os resultados tiveram média de 7,92 + 1,89\%, equivalente a 180,60 + $54,52 \mathrm{mg} / \mathrm{dL}$. O limite foi de 3,34 g / L para participantes diabéticos, 2,60 g / L para parentes e 1,92 g / L para o grupo controle. Conclusões: Portanto, o presente estudo demonstrou que o índice de limiar para percepção do sabor doce é maior em indivíduos com Diabetes Mellitus tipo 2 e seus familiares quando comparados ao grupo controle.

Palavras-chave: Percepção do paladar; Educação em diabetes; Alimentação saudável.

\section{Resumen}

De acuerdo con los reportes de la literatura tanto de la pérdida sensorial de los individuos con Diabetes Mellitus tipo 2 como de la importancia de las interrelaciones familiares en el manejo de esta patología, existe una demanda para evaluar la percepción sensorial de los familiares de individuos con Diabetes tipo 2 Mellitus. En consecuencia, el objetivo de este estudio fue evaluar la percepción del sabor dulce de los diabéticos y sus familiares. Métodos: Para ello, se invitó a participar una muestra de 150 voluntarios, la cual estuvo compuesta por individuos de ambos sexos, con edades comprendidas entre 18 y 59 años, divididos igualmente en tres grupos, constituidos por 50 voluntarios cada uno: individuos no diabéticos, diabéticos individuos y familiares. Además, la concentración de glucosa de todos los participantes se determinó mediante glucemia capilar, y los participantes diabéticos fueron remitidos a un laboratorio externo para realizar la prueba de hemoglobina glucosilada utilizando el inmunoturbidimétrico. Además, se aplicó un cuestionario de información personal y sociodemográfica a los participantes diabéticos y se evaluó la percepción sensorial mediante la prueba de sensibilidad al sabor dulce. Resultados: Los niveles de glucemia de los participantes diabéticos dados por la prueba de Hemoglobina Glicada (HbA1c) revelaron que los resultados tuvieron una media de 7,92 +1,89\%, equivalente a 180,60 +54,52 $\mathrm{mg} / \mathrm{dL}$. El umbral fue de 3,34 g / L para los participantes diabéticos, 2,60 g / L para los familiares y 1,92 g / L para el grupo de control. Conclusiones: Por lo tanto, el presente estudio demostró que el índice de umbral para la percepción del sabor dulce es mayor en individuos con Diabetes Mellitus tipo 2 y sus familiares en comparación con el grupo control.

Palabras clave: Percepción del gusto; Educación en diabetes; Alimentación saludable.

\section{Introduction}

The sensory loss of sweet taste perception in individuals with type 2 Diabetes Mellitus is crucial for the maintenance and aggravation of the pathological condition because this condition can lead to increased consumption of carbohydrates and mortality rates from Diabetes Mellitus (Di Carli et al., 2018; Khera \& Saigal, 2018). The theme was highlighted in a survey in 2016 (Dias et al., 2016), where the rapid method of determining the threshold index was used, pointing to the decrease and / or loss of sensitivity to sweet taste by diabetic individuals. Likewise, a study (Davis, 2020) also found hypersensitivity to sweet taste in that same group.

Although studies have reported the alteration of taste sensitivity in diabetic people, few have analyzed this condition in relatives of individuals with Type 2 Diabetes Mellitus (T2DM).Some articles point to the interrelationship between diabetics and the family, as in a literature review on the subject (Rintala et al., 2013), in which they concluded that more attention should be given to factors such as the family in controlling diabetes. Other research has also revealed the changes that occur in the lives of these families, highlighting those related to food restriction (Malaquias, 2016). According to them, restructuring the diet is one of the most difficult changes that the family faces when dealing with diabetes.

However, food re-education is strictly necessary for good disease control and is closely related to family habits. If no dietary restrictions exist, the taste sensitivity of family members may adjust to that of the T2DM patient. As family members are usually the ones who prepare the food, this sensorial loss could lead to difficulties in controlling the amount of sugar added to foods (Baig et al., 2015; Pamungkas, 2017).

In view of the literature reports of the sensory loss of individuals with T2DM and of the importance of family interrelationships to the management of this pathology, there is a need to evaluate the sensory perception of relatives of T2DM individuals. Therefore, the aim of the present study was to evaluate sweet taste perception of diabetic individuals and their relatives. 


\section{Methodology}

This is a quantitative, descriptive and cross-sectional study carried out from July to November 2016. The study was carried out using a research instrument, a standardized test, applied to two groups of people (test and control) (Pereira et al., 2018) at the Basic Health Unit Julia Magalhães and at the participants' homes, in the municipality of Jequié, Bahia Brazil.

The sample consisted of 150 volunteers of both sexes, aged between 18 and 59 years, divided into three groups: nondiabetic individuals (50 volunteers), diabetic individuals (50 volunteers) and relatives (50 volunteers).

The group of diabetic individuals was formed by people living in the municipality who did not present a diagnosis of diabetes mellitus; the diabetic group was composed of individuals with confirmed diagnosis of T2DM and; the group of relatives consisted of relatives of the participants of the second group, who did not present a diagnosis of T2DM.

\section{Inclusion and exclusion criteria}

The inclusion criteria in the non-diabetic group were:absence of diagnosis of T2DM;residence in Jequié, Bahia, Brazil. The inclusion criteria in the diabetic group were:confirmed diagnosis of T2DMwith laboratory parameters (Glycated Hemoglobin and/or glycemia) in non-conformity with the normal patterns established by the American Diabetes Association ADA (ADA, 2017) For the relatives group, the inclusion criteria were:absence of diagnosis of T2DM;members of the family of the diabetic patient;living in the same house of the diabetic patient.

People under 18 years of age, smokers, pregnant women, individuals with a flu and/or febrile, with complications in the oral cavity (candidosis, prosthesis, etc.), who consumed alcoholic beverages in the last 96 hours before the tests, or who lived alone were excluded from the study.

\section{Ethical aspects}

This research was carried out in accordance with the guidelines and standards of Resolution 466 of December 12, 2012, of the Ministry of Health, on research conducted with humans. The participants were given and signed the Informed Consent Term (ICT).

The research was sent to the Research Ethics Committee of the State University of Southwest of Bahia (REC/UESB) and approved with number of CAAE 46718615.0.0000.0055, the document considers the Declaration of Helsinki.

\section{Socio-demographic characteristics and laboratory evaluation}

Initially, a questionnaire of personal and socio-demographic information was applied to diabetic participants, including the following information: name; age;sex;housing (living alone or not); address; marital status, religion, skin color and schooling.

Glucose concentration of all participants was determined by capillary glycemia. The capillary blood samples were obtained by puncture of the pulp of the middle finger using a non-reusable lancet after antisepsis of the area with $70 \%$ ethanol. The blood obtained at the puncture site was immediately aspirated by the Accu-Check Advantage ${ }^{\circledR}$ Reagent Tape (Roche Diagnóstica Brasil). The test was performed two hours after the last meal of each participant, due to the difficulty of finding the participants in fasting hours.

The diabetic participants were referred to a third-party laboratory to perform the glycated hemoglobin test using the immunoturbidimetric method certified by the NationalGlyco-Hemoglobin Standardization Program (NGSP) (2002), to verify the glycemic levels of the three months prior to collection.

The results of each participant's tests were compared with reference values established by the ADA (ADA, 2017) for postprandial glycemia and glycated hemoglobin. 


\section{Evaluation of gustatory sensitivity}

A test for sweet taste sensitivity was used using the methodology described in the Brazilian Standard (ABNT, 1994) and International Organization for Standartization (ISO 2002).

The quick method of determining threshold index was applied. Each taster went through a series of six 3-AFC (threealternative forced-choice) sensory tests. In each 3-AFC session, the taster was given three samples coded with three random digits, two control samples having only mineral water, and one test sample containing sucrose with increasing concentration along the sessions $(0.5 ; 1 ; 0 ; 2.0 ; 4.0 ; 8.0$ and $16.0 \mathrm{~g} / \mathrm{L}$ ) (ISO, 2002).

Each tester was placed in an individualized room without noise and distractions and was asked to identify the sample that was judged to be different in each of the six test sessions and was given an assessment form.

Samples were served monodically, at room temperature and in disposable cups with a capacity of 50 milliliters. Mineral water was provided for mouth washing between sessions to clean the taste buds, as well as a disposable cup for the taster to discard the samples if he did not ingest them.

Standardized samples were prepared at the Food Technology Laboratory of the State University of Southwest of Bahia. The solutions were prepared with mineral water and sucrose and were quantified by an analytical SHIMADDZU AUW220D scale, then packed in plastic containers at room temperature and protected from light.

\section{Analysis of results}

All data were tabulated and analyzed using Excel® 2013 and the Statistical Package for Social Sciences (SPSS) version 21.0 .

The analysis of the sensitivity test results was performed based on the threshold of each participant, which corresponds to the geometric mean of the highest undetected concentration and the next concentration. For this, data were tabulated and then inserted in the equation below to determine the threshold of each individual evaluated.

$$
A_{i}=\log \left(L_{i}\right)=\frac{\log \left(C_{0}\right)+\log \left(C_{+}\right)}{2}
$$

In the equation, $\mathrm{C} 0$ is the highest concentration undetected/non-recognized by the tasteri, and $\mathrm{C}+$ the lowest concentration detected/recognized by him. Thus, the individual threshold for this taster will be given by:

$$
L_{\mathrm{i}}=10^{A \mathrm{i}}
$$

After determining the thresholds of each participant, a second equation was applied to obtain the threshold of the three groups, calculating the geometric mean of the Li values:

$$
B=\frac{1}{n}+\sum_{\log (t i n)}
$$

Thus, for a group of $\mathrm{n}$ tasters, we have:

$$
L_{g}=10^{b}
$$


The Kolmogorov-Smirnov normality test was used to verify whether the individual threshold index of the three groups followed a normal distribution.TheMan Whitney test was used to make comparisons of numerical variables with unpaired samples and non-normal distribution between control and T2DM individuals; control individuals and relatives; and relatives and T2DM individuals.

A descriptive analysis of the socio-demographic information of the diabetic participants was made. Then, the Kolmogorov-Smirnov normality test was applied to verify whether the age and sex of the participants of the three groups followed a normal distribution. The Kruskal-Wallis test was applied for numerical data and unpaired samples with non-normal distribution to verify whether there was a significant difference between groups in relation to age and sex of the participants.

\section{Results}

Sociodemographic data of the three groups are presented in Table 1. The analysis of Table 1 shows that there was no significant difference ( $p>0.05$ ), according to the Kruskal-Wallis test, between groups in relation to age and sex. Thus, the influence of these confounders on taste thresholds was assumed to be insignificant.

Table 1 - Sociodemographic data of the individuals studied.

\begin{tabular}{|c|c|c|c|c|}
\hline & \multirow{2}{*}{$\begin{array}{l}\text { T2DM } \\
\text { Individuals }\end{array}$} & \multirow[t]{2}{*}{ Control } & \multicolumn{2}{|c|}{ Relative } \\
\hline & & & $\mathbf{s}$ & \multirow{2}{*}{$\frac{\text {-value }}{>0.05}$} \\
\hline Age, mean \pm SD (years) & $47.82 \pm 9.24$ & $45.32 \pm 10.32$ & $45.30 \pm 9.80$ & \\
\hline Female, n (\%) & $39(78)$ & $36(72)$ & $35(70)$ & $>0.05$ \\
\hline Marital status, n (\%) & $13(26)$ & & & \\
\hline Single & $33(66)$ & & & \\
\hline Married & $4(8)$ & & & \\
\hline \multicolumn{5}{|l|}{ Other } \\
\hline Religion n (\%) & $17(34)$ & & & \\
\hline Chatolic Evangelical & $28(56)$ & & & \\
\hline Other & $5(10)$ & & & \\
\hline Skin color, n (\%) & $8(16)$ & & & \\
\hline White & $9(18)$ & & & \\
\hline Black & $33(66)$ & & & \\
\hline \multicolumn{5}{|l|}{ Brown } \\
\hline Schooling, n (\%) & $20(40)$ & & & \\
\hline \multicolumn{5}{|l|}{ IPS } \\
\hline CPS & $10(20)$ & & & \\
\hline IHS & $5(10)$ & & & \\
\hline CHS & $8(16)$ & & & \\
\hline IL & $6(12)$ & & & \\
\hline Other & $1(2)$ & & & \\
\hline
\end{tabular}

SD: Standard Deviation; IPS: Incomplete Primary School; CPS: Incomplete Primary School; IHS: Incomplete High School; CHS: Complete High School; IL: Illiterate. The values in the parentheses indicate the percentages. Source: Authors.

The results of the postprandial capillary glycemia test presented a mean of $90.66 \pm 11.41 \mathrm{mg} / \mathrm{dL}, 184.22 \pm 67.90$ 
$\mathrm{mg} / \mathrm{dL}$ and $100.48 \pm 9.23 \mathrm{mg} / \mathrm{dL}$ for the non-diabetic, diabetics and relatives groups, respectively.

Glycemic levels of the diabetic participants were also verified by Glycated Hemoglobin (HbA1c) test and the results had a mean of $7.92+1.89 \%$, equivalent to $180.60+54.52 \mathrm{mg} / \mathrm{dL}$.

Gustatory sensitivity to sweet stimuli was evaluated through the quick method of determining the threshold index. The number of correct answers per session and per group is shown in Table 2.

Table 2 - Number of correct answers per session in the threshold index determination test.

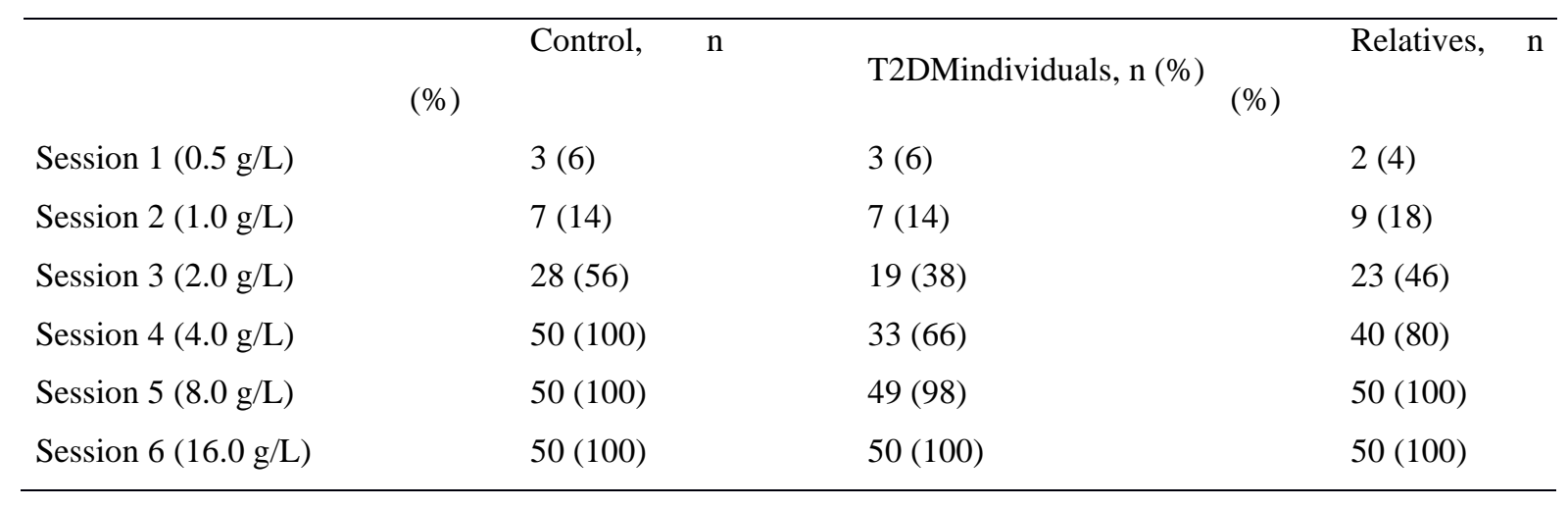

Source: Authors.

Table 2 made it possible to calculate the threshold index of each participant and identify the mean thresholds for detection of sweet flavor. This threshold was $3.34 \mathrm{~g} / \mathrm{L}$ for diabetic participants, $2.60 \mathrm{~g} / \mathrm{L}$ for relatives, and $1.92 \mathrm{~g} / \mathrm{L}$ for the control group. Samples did not follow a normal distribution and the Man Whitney test was applied;there was a statistically significant difference $(\mathrm{p}<0.05)$ for the variable mean threshold index between the control and diabetic individuals and between control individuals and relatives.

\section{Discussion}

The results of the postprandial capillary glycemia test of the diabetic participants showed that $76 \%$ had postprandial capillary glycemia above the normal values recommended by the American Diabetes Association (ADA, 2017) (less than 140 $\mathrm{mg} / \mathrm{dL})$.

The results of the Glycated Hemoglobin (HbA1c) test in diabetic patients were also analyzed. This test has been established as a reference method for monitoring glycemic levels in the medium term, since HbA1C reflects the average glycemia of the last three months before the analysis of glucose in the patient.

ADA (ADA, 2017) recommends that subjects with diabetes mellitus perform the HbAlc test at least twice a year and sets values below $7.0 \%$, equivalent to $154 \mathrm{mg} / \mathrm{dL}$ glucose, as target for good glycemic control. In this sense, the tests applied, i.e. Glycated Hemoglobin and postprandial capillary glycemia, showed that diabetic individuals did not present a good control of the disease according to ADA and this may be related to non-adherence to prescribed treatment, such as the non-adoption of adequate feeding.

The characteristics of diabetic individuals with altered capillary glucose were demonstrated (Fernandes et al., 2014). They observed that $69 \%$ of the individuals presented difficulties to follow the treatment, and feeding was the more difficult aspect. In fact, dietary prescription is considered the most difficult behavioral and social factor to be modified, and the more changes are required in the routine of the individual, the more difficult adherence will be.

The influence of eating habits on the onset of diabetes was assessed and found that individuals who eat healthy also have lower blood glucose levels when compared to individuals with incorrect eating habits, and the carbohydrates in the diet 
are primarily responsible for that difference (de Castro, 2016). Thus, excessive carbohydrate consumption is considered an important dietary factor and may be determinant for the appearance of other comorbidities (Wermeling et al., 2014).

The test of sweet taste sensitivity showed that that a larger number of people were able to identify the sucrose solution in sessions 4, 5 and 6, the sessions in which sugar concentrations were higher: $4 \mathrm{~g} / \mathrm{L}, 8 \mathrm{~g} / \mathrm{L}$ and $16 \mathrm{~g} / \mathrm{L}$, respectively. Diabetic individuals had a greater difficulty to perceive sweet taste; only $38 \%$ identified the sweet taste in session 3, while 66\%, $98 \%$ and $100 \%$ perceived the sweet taste in sessions 4,5 and 6, respectively. The entire non-diabetic group had already noticed the sweet taste in session 4 and continued recognizing it up to sessions 5 and 6.

Regarding the relatives of diabetic patients, a greater sensitivity to sweet taste was observed in sessions 4,5 and 6 compared to the diabetic group, presenting $80 \%$ of accuracy in session 4 and $100 \%$ in the last two sessions. However, these values were lower than those of the non-diabetic group.

In the analysis of the results of the threshold index of each participant, it was observed that the diabetic individuals and relatives presented threshold values higher than non-diabetic individuals. Thus, the sensitivity for sweet stimuli of diabetic individuals and of their relatives was lower when compared to the control group.

The comparison of threshold indices by the Man Whitney test, at 5\% probability, showed no significant difference between diabetic individuals and relatives. Thus, no difference was found in taste sensitivity between diabetic individuals and relatives. This is worrying because the decrease in the gustatory sensitivity of family members may indicate a possible adaptation of taste to the diabetic person and this increase the consumption of sugar by the family and predispose to diseases related to this consumption, such as obesity and Diabetes Mellitus itself.

In this sense, it is observed that diabetic people are often the ones who prepare the food menu for the whole family and because they have little sensitivity to sweet stimuli, they may add excessive amount of fine carbohydrates to the foods, or even when a relative is the person who prepares the food, the diabetic person may demand the preparation of more sweet food.

High consumption of carbohydrates can lead to an adaptation of the taste of relatives and consequent reduction of gustatory sensitivity. Decrease and/or loss of sensitivity to sweet food may contribute to increasing the ingestion of refined carbohydrates (Wasalathanthri et al., 2014; Sakai et al., 2019). In turn, this becomes a risk factor for diabetic people and their relatives, because the higher the sugar intake, the greater is the need for insulin production and release. The situation implies a greater the need for glucose uptake; these factors when associated may predispose the worsening of the prognosis of the diabetic patient, as well as induce family members to situations such as obesity and states of glucose tolerance.

Practices related to food are determined in family and social life. The preparation of food for diabetic individuals should include attention of family members to their needs and preferences (Wermeling et al., 2014). It is often necessary that other people - siblings, parents, children, spouses - change their eating habits aiming at a more adequate diet for the diabetic person. Recent research (Landa-Anell, 2020) indicates that separate meals for diabetic patients can be a barrier to adherence to nutritional therapy; patients may not be able to make their own food or they may not be motivated to eat and control the food on their own.

It is a consensus that adequate diabetes control cannot be achieved without food planning (Arana et al., 2019). The diet for individuals with diabetes mellitus aims to contribute to the normalization of glycemia, achieve and maintain adequate body weight, decrease cardiovascular risk factors, and prevent acute and chronic complications of the disease (Leslie et al., 2016).

One of the possible explanations for the results of loss of gustatory sensitivity in individuals with Type 2 Diabetes Mellitus is hypossiviation, xerostomia and low production of glicine. In addition, the deficiency or absence of gustine interferes with the salivation and maturation of the taste buds, causing a change in the perception of taste (Wasalathanthri et al., 2014). 
In a review of clinical and biochemical evaluations with over 5000 patients, it was found that inhibition of taste buds and consequent loss or distortion of taste are associated with pathophysiology of chronic diseases such as Diabetes Mellitus (Henkin et al., 2013).

\section{Conclusion}

The present study demonstrated that the threshold index for sweet taste detection is higher in individuals with Type 2 Diabetes Mellitus and their relatives when compared to the control group. Thus, the gustatory sensitivity to sweet taste of these participants is lower, requiring higher sugar concentrations to feel this taste in food.

It is noteworthy that, although researches have evaluated the threshold indices if diabetic patients, this is the first study performed with relatives of individuals with Type 2 Diabetes Mellitus that was able to demonstrate the reduction of taste sensitivity of relatives.

Therefore, it is appropriate for health professionals to carry out the evaluation of the threshold index in diabetic patients and their relatives during the follow-up T2DM patients, since they can help prevent the onset of diseases related to the high consumption of carbohydrates.

It is worth mentioning that new investigations about sensory perception to other tastes and the relationship with Type 2 Diabetes Mellitus and better study designs can be incorporated into future studies on this comorbidity.

\section{References}

American Diabetes Association (ADA). (2017). Classification and diagnosis of diabetes. Sec. 2. In Standards of Medical Care in Diabetes. Diabetes Care 40; S11-S24.

Arana, M. A., Valderas, J. M., \& Solomon, J. (2019). Being tested but not educated-a qualitative focus group study exploring patients' perceptions of diabetic dietary advice. BMC family practice, 20(1), 1-7.

Associação Brasileira de Normas Técnicas (ABNT). (1994) Norma Brasileira nº 13172: Teste de sensibilidade em análise sensorial. ABNT.

Baig, A. A., Benitez, A., Quinn, M. T., \& Burnet, D. L. (2015). Family interventions to improve diabetes outcomes for adults. Annals of the New York Academy of Sciences, 1353(1), 89.

Davis, T. M. (2020). Fenofibrate and Impaired Taste Perception in Type 2 Diabetes. The American journal of case reports, 21 , e927647-1.

De Carli, L., Gambino, R., Lubrano, C., Rosato, R., Bongiovanni, D., Lanfranco, F., \& Bo, S. (2018). Impaired taste sensation in type 2 diabetic patients without chronic complications: a case-control study. Journal of endocrinological investigation, 41(7), 765-772.

de Castro, A. A. M., Kumpel, C., Porto, E. F., Menezes, E., Carpes, M. F., Malheiros, R. T., \& Oliveira, S. C. (2016). Análise comparativa dos níveis glicêmicos em indivíduos que praticam atividade física e sedentários. Life Style, 3(1), 49-66.

Dias, V. R., Brazil, J. M., Almeida, J. A. R., de Souza Silva, C., \& Milagres, M. P. (2016). Avaliação da percepção sensorial ao gosto doce em pessoas com Diabetes Mellitus tipo 2. Rev Rene, 17(4), 483-489.

Fernandes, A. M. T., Henriques, E. L. V., \& Amendola, F. (2014). Características de usuários portadores de diabetes mellitus tipo II com glicemia capilar alterada em um pronto atendimento municipal. Revista Saúde-UNG-Ser, 8(1-2), 6-15.

Henkin, R. I., Levy, L. M., \& Fordyce, A. (2013). Taste and smell function in chronic disease: A review of clinical and biochemical evaluations of taste and smell dysfunction in over 5000 patients at The Taste and Smell Clinic in Washington, DC. American journal of otolaryngology, 34(5), 477-489.

International Organization for Standartization. (2002). Sensory analysis. Methodology. General guidance for measuring odour, flavour and taste detection thresholds by a three-alternative forced-choice (3-AFC) procedure. In: ISO International Standard. N ${ }^{\circ}$ 13301/International Organization for Standardization, Geneva: International Organization for Standartization: 27.

Khera, S., \& Saigal, A. (2018). Assessment and evaluation of gustatory functions in patients with diabetes mellitus type II: a study. Indian journal of endocrinology and metabolism, 22(2), 204.

Landa-Anell, M. V., Melgarejo-Hernández, M. A., García-Ulloa, A. C., Del Razo-Olvera, F. M., Velázquez-Jurado, H. R., \& Hernández-Jiménez, S. (2020). Barriers to adherence to a nutritional plan and strategies to overcome them in patients with type 2 diabetes mellitus; results after two years of follow-up. Endocrinologia, diabetes y nutricion, 67(1), 4-12.

Leslie, W. S., Ford, I., Sattar, N., Hollingsworth, K. G., Adamson, A., Sniehotta, F. F., \& Lean, M. E. (2016). The Diabetes Remission Clinical Trial (DiRECT): protocol for a cluster randomised trial. BMC Family Practice, 17(1), 1-10. 
Research, Society and Development, v. 10, n. 3, e41610313525, 2021

(CC BY 4.0) | ISSN 2525-3409 | DOI: http://dx.doi.org/10.33448/rsd-v10i3.13525

Malaquias, T. D. S. M., Marques, C. D. C., de Paula Faria, A. C., Pupulim, J. S. L., Marcon, S. S., \& Higarashi, I. H. (2016). A criança e o adolescente com diabetes mellitus tipo 1: desdobrar do cuidado familiar. Cogitare Enfermagem, 21(1).

Pamungkas, R. A., Chamroonsawasdi, K., \& Vatanasomboon, P. (2017). A systematic review: family support integrated with diabetes self-management among uncontrolled type II diabetes mellitus patients. Behavioral Sciences, 7(3), 62.

Pereira, A. et al. Metodologia da pesquisa científica. UFSM.

Rintala, T. M., Jaatinen, P., Paavilainen, E., \& Åstedt-Kurki, P. (2013). Interrelation between adult persons with diabetes and their family: a systematic review of the literature. Journal of family nursing, 19(1), 3-28.

Sakai, C., Abe, S., Kouzuki, M., Shimohiro, H., Ota, Y., Sakinada, H., \& Hanaki, K. (2019). A randomized placebo-controlled trial of an oral preparation of high molecular weight fucoidan in patients with type 2 diabetes with evaluation of taste sensitivity. Yonago acta medica, 62(1), 014-023.

Wasalathanthri, S., Hettiarachchi, P., \& Prathapan, S. (2014). Sweet taste sensitivity in pre-diabetics, diabetics and normoglycemic controls: a comparative cross sectional study. BMC endocrine disorders, 14(1), 1-7.

Wermeling, M., Thiele-Manjali, U., Koschack, J., Lucius-Hoene, G., \& Himmel, W. (2014). Type 2 diabetes patients' perspectives on lifestyle counselling and weight management in general practice: a qualitative study. BMC family practice, 15(1), 1-7. 